\title{
OPTIMASI PEREAKSI WARNA CARIK UJI UNTUK ANALISIS KUALITATIF KALIUM BROMAT PADA MAKANAN
}

\author{
${ }^{1}$ Riesma Azhar Falahul Alam, ${ }^{2}$ Hilda Aprilia Wisnuwardhani, ${ }^{3}$ Rusnadi \\ ${ }^{1,2,3}$ Program Studi Farmasi, FMIPA, Universitas Islam Bandung \\ email:riesmaazhar@gmail.com
}

\begin{abstract}
ABSTRAK
Bahan tambahan pangan biasanya ditambahkan untuk meningkatkan mutu makanan. Namun, sering pula dijumpai penambahan zat yang dilarang penggunaannya dalam makanan. Salah satunya adalah kalium bromat. Untuk itu diperlukan suatu pereaksi untuk pendeteksian kalium bromat yang dapat dijadikan carik uji agar pendeteksian kalium bromat menjadi lebih mudah. Dalam penelitian ini dilakukan optimasi volume nanopartikel Ag dan konsentrasi acid red 14 sebagai pereaksi untuk carik uji kalium bromat. Acid red 14 ini akan teroksidasi menjadi tidak berwarna dengan adanya kalium bromat. Dari hasil penelitian ini, setiap $25 \mathrm{~mL}$ pereaksi terdiri dari $10 \mathrm{~mL}$ nanopartikel Ag; 0,002 $\mathrm{mM}$ acid red 14; dan $1 \mathrm{~mL} \mathrm{H}_{2} \mathrm{SO}_{4}$ 0,2 M.
\end{abstract}

Kata kunci: Kalium bromat, nanopartikel Ag, acid red 14.

\begin{abstract}
Food additives are usually added to improve food quality. But banned substance are often found e.g potassium bromate. Therefore we need a reagent to analyze the presence of potassium bromate and the reagent will be used to make a strip test for practical uses in detection potassium bromate. In this study, optimization of Ag nanoparticles volume and acid red 14 concentration has been done. Acid Red 14 was oxidized to colorless in the presence of potassium bromate. Result showed that each $25 \mathrm{~mL}$ reagent consist of $10 \mathrm{~mL} \mathrm{Ag} \mathrm{nanopaticles;} 0,002 \mathrm{mM}$ acid red 14; and $1 \mathrm{~mL} \mathrm{0,2} \mathrm{M} \mathrm{H}_{2} \mathrm{SO}_{4}$.
\end{abstract}

Key words: Potassium bromate, Ag nanopaticles, acid red 14

\section{PENDAHULUAN}

Sumber energi dapat diperoleh dari berbagai jenis makanan. Untuk meningkatkan mutu, produsen tidak jarang menambahkan bahan tambahan pangan ke dalam makanan. Namun makanan pun dapat menjadi sumber penyakit dikarenakan adanya zat berbahaya di dalamnya. Kalium bromat merupakan salah satu bahan yang dilarang pemakaiannya dalam makanan berdasarkan Peraturan Menteri Kesehatan Republik Indonesia Nomor 33 Tahun 2012 tentang Bahan Tambahan Pangan (Menteri Kesehatan, 2012).
Kalium bromat $\left(\mathrm{KBrO}_{3}\right)$ biasanya digunakan sebagai oksidan, bahan tambahan makanan kaleng, bahan pengolahan wol, peningkat mutu tepung, memperkuat adonan, dan digunakan dalam produksi malt barley (Badan POM RI, 2015).

Dari hasil penelitian menunjukkan bahwa kalium bromat berefek sitotoksik dan karsinogenik terhadap ginjal (Kolisetty dkk, 2013). Dari pengujan toksisitas subkronik yang dilakukan terhadap tikus F344 memperlihatkan adanya peningkatan yang signifikan terhadap droplet hyalin ginjal, proliferasi sel ginjal, akumulasi $\alpha_{2 \mu}$ - 
globulin, dan terjadinya oksidasi pada ginjal (Dodd $\mathrm{dkk}, 2013) . \mathrm{KBrO}_{3}$ pun memiliki respon genotoksik yang kuat terhadap sel limfoma L5178Y (Priestley dkk, 2010). Namun dari hasil penelitian, ditemukan adanya penambahan kalium bromat pada 60 sampel roti di daerah Binjai (Ayuningtias dkk, 2014). Sebelumnya telah dilakukan penelitian yang menyatakan bahwa acid red 14 yang menggunakan nanopartikel Ag sensitif terhadap bromat dalam tepung dan air dalam botol (Farmany dkk, 2014). Oleh karena itu, diperlukan penelitian lebih lanjut untuk mengetahui efektifitas acid red 14 dan nanopartikel Ag jika dibuat suatu carik uji.

Penelitian ini bertujuan untuk mencari kombinasi pereaksi warna carik uji baru untuk mendeteksi kalium bromat $\left(\mathrm{KBrO}_{3}\right)$ dalam makanan dengan menggunakan acid red 14 sebagai reduktor dengan penambahan nanopartikel $\mathrm{Ag}$ sebagai katalisator. Hasil optimasi pereaksi warna ini nantinya digunakan untuk membuat carik uji yang digunakan untuk mendeteksi kalium bromat dalam makanan.

\section{METODE PENELITIAN}

Penelitian ini dilakukan di Laboratorium Riset Prodi Farmasi Universitas Islam Bandung. Volume nanopartikel Ag yang digunakan dievaluasi dengan menggunakan metode spektrofotometri UV-sinar tampak sedangkan konsentrasi acid red 14 dievaluasi secara visual.

\subsection{Bahan}

Bahan yang digunakan pada penelitian ini diantaranya adalah akuades; akuabides; amilum; perak nitrat (Merck, analytical grade); natrium hidroksida (Merck, analytical grade); asam sulfat (analytical grade); acid red 14 50\% (SigmaAldrich, analytical grade); dan kalium bromat (Merck, analytical grade).

\subsection{Alat}

Alat-alat yang digunakan diantaranya adalah alat-alat gelas yang biasa dipakai di laboratorium, oven (Memmert), pH meter (SevenCompact S220), Spektrofotometer UV-sinar tampak (Shimazu UV Mini-1240), dan timbangan analitik (Mettler Toledo AL 204).

\subsection{Sintesis Nanopartikel Ag}

Nanopartikel Ag dibuat dengan cara menambahkan $400 \mu \mathrm{L} \mathrm{AgNO}_{3}$ 0,1 M ke dalam 100 $\mathrm{mL}$ larutan amilum $0,1 \%(\mathrm{~b} / \mathrm{v})$. Kemudian diaduk selama 1 jam. pH larutan dicek dan selanjutnya dilakukan adjust $\mathrm{pH}$ dengan penambahan larutan $\mathrm{NaOH}$ 0,1 M hingga mencapai pH 8. Pada reaksi awal, campuran tidak berwarna. Setelah 1 jam, larutan akan berubah menjadi kuning muda yang mengindikasikan adanya pembentukan Ag nanopartikel. Campuran tersebut kemudian dijaga pada suhu $50^{\circ} \mathrm{C}$ selama 24 jam. Akibat reaksi yang terjadi, larutan campuran akan berubah menjadi kuning (Farmany dkk, 2014).

\subsection{Prosedur}

Optimasi volume nanopartikel Ag dilakukan dengan membuat sejumlah pereaksi warna dengan volume penambahan larutan nanopartikel Ag yang berbeda-beda yaitu dengan volume 5, 10, dan 15 $\mathrm{mL}$. Selanjutnya masing-masing pereaksi ditambahkan $1 \mathrm{~mL} \quad \mathrm{KBrO}_{3}$ dengan konsentrasi 10000 ppm. Setelah 5 menit, dilihat absorbansinya dengan Spektrofotometri UV-sinar tampak pada $\lambda$ $516 \mathrm{~nm}$. Kemudian dipilih volume penambahan 
nanopartikel Ag yang memiliki penurunan absorbansi yang paling besar.

Optimasi konsentrasi acid red 14 dilakukan dengan membuat sejumlah pereaksi warna dengan penambahan konsentrasi acid red 14 yang berbedabeda yaitu $0,002 \mathrm{mmol} ; 0,005 \mathrm{mmol} ; 0,02 \mathrm{mmol}$; dan 0,05 mmol. Selanjutnya masing-masing pereaksi ditambahkan $1 \mathrm{~mL} \quad \mathrm{KBrO}_{3}$ dengan konsentrasi 10000 ppm. Setelah 10 menit, dilihat pereaksi mana yang berubah warna menuju tidak berwarna.

\section{HASIL DAN PEMBAHASAN}

\subsection{Optimasi volume nanopartikel Ag}

Pada penyiapan pereaksi warna, dilakukan optimasi volume nanopartikel Ag yang digunakan. Optimasi ini dilakukan dengan menambahkan volume nanopartikel Ag yang berbeda-beda, yaitu 5, 10, dan $15 \mathrm{~mL}$. Kemudian dipilih volume nanopartikel Ag yang penurunan absorbansi dari acid red 14 yang paling besar ketika ditambahkan larutan $\mathrm{KBrO}_{3} 10000$ ppm. Penilaian tersebut berdasarkan reaksi oksidasi acid red 14 oleh $\mathrm{KBrO}_{3}$ dengan bantuan katalis nanopartikel Ag dimana acid red 14 akan teroksidasi menjadi senyawa yang tidak berwarna sehingga menyebabkan penurunan absorbansi dari acid red 14. Dari hasil penelitian Farmany dkk (2014) menyatakan bahwa reaksi oksidasi acid red 14 dalam media asam sulfat berlangsung sangat lambat sehingga diperlukan suatu katalis yang dapat mempercepat reaksi tersebut. Dan pada penelitian tersebut digunakan nanopartikel Ag sebagai katalis.

Dari hasil pengujian didapatkan volume nanopartikel Ag dengan penurunan absorbansi yang paling besar yaitu pada volume $10 \mathrm{~mL}$. Nanopartikel Ag ini dapat menjadi katalis yang baik karena ukurannya yang berupa nanopartikel yang memungkinkan luas permukaannya semakin besar dan aktivitas katalitiknya semakin besar. Namun pada pengujian yang dilakukan, volume nanopartikel Ag sebesar $15 \mathrm{~mL}$ memiliki aktivitas yang lebih rendah dibandingkan dengan volume yang $10 \mathrm{~mL}$, data absorbansi dapat dilihat pada Tabel 1. Hal ini dapat terjadi dikarena adanya pengaruh $\mathrm{pH}$ dalam reaksi tersebut. $\mathrm{pH}$ dari nanopartikel Ag yang dibuat sebesar 8, sedangkan reaksi oksidasi dari acid red 14 ini harus dalam suasana asam, sehingga $\mathrm{pH}$ yang lebih besar akan sangat mempengaruhi laju reaksi oksidasi dari acid red 14 oleh $\mathrm{KBrO}_{3}$. Dan pada akhirnya dipilihlah volume nanopartikel Ag untuk membuat $25 \mathrm{~mL}$ pereaksi yaitu sebesar $10 \mathrm{~mL}$. Namun dengan adanya katalis nanopartikel Ag ini masih membutuhkan waktu yang cukup lama agar terbentuk larutan yang tidak berwarna. Hal ini dapat terjadi karena kualitas nanopartikel Ag yang dihasilkan berbeda dengan yang seharusnya. 
Tabel 1. Hasil optimasi volume nanopartikel Ag

\begin{tabular}{|c|c|c|c|c|}
\hline \multirow[b]{2}{*}{ No } & \multirow[b]{2}{*}{$\begin{array}{c}\text { Volume } \\
\text { Nanopartikel Ag }\end{array}$} & \multicolumn{2}{|c|}{ Absorbansi acid red 14} & \multirow[b]{2}{*}{$\begin{array}{l}\text { Perubahan } \\
\text { absorbansi }\end{array}$} \\
\hline & & $\begin{array}{c}\text { Sebelum } \\
\text { penambahan AgNP }\end{array}$ & $\begin{array}{c}\text { Sesudah } \\
\text { penambahan AgNP }\end{array}$ & \\
\hline 1 & $5 \mathrm{~mL}$ & 0,332 & 0,26 & 0,072 \\
\hline 2 & $10 \mathrm{~mL}$ & 0,473 & 0,239 & 0,234 \\
\hline 3 & $15 \mathrm{~mL}$ & 0,621 & 0,47 & 0,151 \\
\hline
\end{tabular}

\subsection{Optimasi konsentrasi acid red 14}

Dalam pembuatan pereaksi warna ini dilakukan pula optimasi terhadap konsentrasi acid red 14 yang digunakan. Pada penelitian Farmany dkk (2014) digunakan 2 mmol acid red 14 untuk membuat $25 \mathrm{~mL}$ pereaksi. Namun, dalam pengujian ini terlihat bahwa warna pereaksi yang terbentuk sangat pekat dan ini sangat mempengaruhi reaksi yang terjadi, dimana menurut Farmany dkk (2014), konsentrasi acid red 14 yang besar akan menurunkan sensitivitas reaksi yang dihasilkan. Oleh karena itu, dilakukan optimasi dengan menurunkan konsentrasi acid red 14 yang digunakan. Dari hasil pengujian warna dengan konsentrasi 0,005 ; 0,02 ; dan $0,05 \mathrm{mmol}$ tidak terdapat perubahan warna yang terlihat oleh mata saat ditambahkan dengan larutan $\mathrm{KBrO}_{3} 10000$ ppm. Maka, dibuat pereaksi warna dengan penambahan acid red 14 dengan konsentrasi 0,002 mmol dimana pada konsentrasi tersebut terdapat perubahan warna yang terlihat dengan mata, perubahan warna pereaksi dapat dilihat pada Tabel 2.

Tabel 2. Hasil optimasi konsentrasi acid red 14

\begin{tabular}{|c|c|c|c|c|}
\hline \multirow[b]{2}{*}{ No } & \multirow{2}{*}{$\begin{array}{c}\text { Konsentrasi acid } \\
\text { red } 14\end{array}$} & \multicolumn{3}{|c|}{ Gambar } \\
\hline & & Pereaksi & Pereaksi + akuades & $\begin{array}{l}\text { Pereaksi }+ \text { kalium } \\
\text { bromat } 10000 \mathrm{ppm}\end{array}$ \\
\hline 1 & $0,002 \mathrm{mmol}$ & & & \\
\hline 2 & $0,005 \mathrm{mmol}$ & & & \\
\hline 3 & $0,02 \mathrm{mmol}$ & & & \\
\hline 4 & $0,05 \mathrm{mmol}$ & & & \\
\hline
\end{tabular}




\section{KESIMPULAN}

Pereaksi warna yang digunakan untuk menganalisis adanya kalium bromat terdiri dari 1 $\mathrm{mL} \mathrm{H}_{2} \mathrm{SO}_{4}$ 0,2 M; 0,002 mmol acid red 14; dan 10 $\mathrm{mL}$ nanopartikel Ag yang kemudian ditambahkan akuabides hingga $25 \mathrm{~mL}$.

\section{UCAPAN TERIMA KASIH}

Terima kasih dan penghargaan yang sebesarbesarnya kami ucapkan pada Program Studi Farmasi Universitas Islam Bandung yang telah mendanai penelitian mandiri ini.

\section{DAFTAR PUSTAKA}

Ayuningtias, C., Nasution, E., dan Jumirah., 2015. Kajian Keamanan Pangan Jajanan Roti Di Toko Roti Kecamatan Binjai Kota Dan Binjai Utara Tahun 2014, Gizi Kesehatan Masyarakat, Fakultas Kesehatan Masyarakat, Universitas Sumatera Utara, Medan, 8.

Badan POM RI., 2015. Kalium Bromat, Katalog Kalium Bromat, Jakarta, 1.

Dodd, D.E., Layko, D.K., Cantwell, K.E., Willson, G.A., dan Thomas R.S., 2013. 'Subchronic
Toxicity Evaluation Of Potassium Bromate In Fisher 344 Rats', Enviromental Toxicology and Pharmacology, 36(2013): 1227-1234.

Farmany A, Mortazavi SS, Hashemi E, dan Sahrei R., 2014, "A New Catalytic Oxidation Method for Sensitive Quantification of Bromate in Flours dan Bottled Water Using AgNPs", Environmental Monitoring Assessment, Springer Sciens+Business Media Dordrecht, 186: 1371-1375.

Kolisetty, N., Bull, R.J., Muralidhara, S., Costyn, L.J., Delker, Z.G., Cotruvo., J.A., Fisher, J.W., Cummings, B.S., 2013. "Association Of Brominated Proteins and Changes In Protein Expression In The Rat Kidney With Subcarcinogenic To Carcinogenic Doses Of Bromate", Toxicology and Applied Pharmacology, 272(2):_391-398.

Menteri Kesehatan RI., 2012. Peraturan Menteri Kesehatan Republik Indonesia Nomor 003 Tahun 2012 Tentang Bahan Tambahan Pangan, POM RI, Jakarta: 21.

Priestley, C.C., Green, R,M., Fellows, M.D., Doherty, A.T., Hodges N.J., dan O'Donovan, M.R., 2010. 'Anomalous Response Induce In Mouse Lymphoma L5178Y Cell By Potassium Bromate', Toxicology 267(2010): 45-53. 